\title{
Anatomy of Eastern Niger Rift Basin with Specific References of Its Petroleum Systems
}

\author{
Kabir Shola Ahmed1,2*, Keyu Liư1,2, Arthur Paterne Mioumnde1,2,3, Kouassi Louis Kra1,2, \\ Abigail Adu-Asante Kuttin',2, Kue Petou Rokis Malquaire ${ }^{2,4}$, \\ Kusi Micheline Michelle-Alexia Ngum ${ }^{3}$
}

${ }^{1}$ Key Laboratory of Deep Oil and Gas, China University of Petroleum (East China), Qingdao, China

${ }^{2}$ School of Geosciences, China University of Petroleum (East China), Qingdao, China

${ }^{3}$ Laboratory of Ore Processing, Institute of Geological and Mining Research, Yaoundé, Cameroon

${ }^{4}$ National Institute of Cartography, Yaoundé, Cameroon

Email: *sholli242@yahoo.com

How to cite this paper: Ahmed, K.S., Liu, K., Mioumnde, A.P., Kra, K.L., Kuttin, A.A.-A., Malquaire, K.P.R. and Ngum, K.M.M.-A. (2020) Anatomy of Eastern Niger Rift Basin with Specific References of Its Petroleum Systems. International Journal of Geosciences, 11, 305-324. https://doi.org/10.4236/ijg.2020.115016

Received: February 10, 2020

Accepted: May 9, 2020

Published: May 12, 2020

Copyright $\odot 2020$ by author(s) and Scientific Research Publishing Inc. This work is licensed under the Creative Commons Attribution International License (CC BY 4.0).

http://creativecommons.org/licenses/by/4.0/ (c) (i) Open Access

\section{Abstract}

An attempt is made in this paper to present the dynamics of the Eastern Niger Rift Basin (ENRB) with references to the key features and processes of petroleum systems based on published information. The Eastern Niger Basin is a superimposed rift basin with sedimentary structures emplaced during two rifts episodes. The Cretaceous episode is characterized by large, tilted normally faulted blocks trending NW-SE, that were reactivated in the Paleogene, while the Paleogene episode is characterized by normal faulted blocks that trend NNW-SSE. The rifting resulted in different basin structures with the north section dominated by asymmetric half-grabens while the south section is dominated by full-grabens. Three source rocks each belonging to three different play fairways exist: 1) The Paleogene Sokor-1 Member source belongs to second cycle syn-rift play associated with fluvial/deltaic facies; 2) Cretaceous Yogou and Donga sources from first cycle post-rift play associated with alluvial/fluvial/deltaic and marine clastic and carbonate facies; and 3) Cretaceous Yogou source from first cycle transitional play associated with mudstone and shale of transitional facies. The ENRB comprises two sourcereservoir-seal assemblages: a lower assemblage of Upper Cretaceous and an Upper assemblage of the Paleogene. Except for the Yogou source which possesses a self-contained petroleum system, the rest of the source rocks release their oils into the Paleogene Sokor-1 Member reservoir sealed regionally by the Oligocene Sokor-2 Member. The Paleogene assemblage is charged from the Upper Cretaceous Yogou Formation through fractures emplaced during the rifting episodes.
\end{abstract}




\section{Keywords}

Rift, Petroleum Source Rock, Oil Migration, Basin Evolution, Eastern Niger Rift Basin

\section{Introduction}

The Republic of Niger is a Sub-Saharan landlocked nation in West Africa. It is confined by seven countries; on the west by Burkina Faso and Mali, on the east by Chad, on the north by Algeria and Libya and on the south by Benin and Nigeria (Figure 1). It has an area of $1,267,000$ square $\mathrm{km}^{2}$ and a population of about 21.4 million people. It is among the most recent members of the oil-producing countries with her first production launched in 2011, even though oil exploration dated back to 1958 .

Two large sedimentary basins exist in Niger; Iullemeden (or Western) Basin and Eastern Basin separated by a $1.5 \mathrm{~km}$ tall and $7700 \mathrm{~km}$ long north-south trending Air Massif mountain [1] [2]. The Western Basins belongs to a Paleozoic tectonic and sedimentary regime. It is a $1000 \mathrm{~km}$ long and $900 \mathrm{~km}$ wide depression [2] containing the Cambrian to Carboniferous sedimentary successions overlying a Pre-Cambrian basement of granites and metamorphic rocks. The basin contains potential petroleum system elements but has no oil discovery so far [1]. The Eastern Basin runs $700 \mathrm{~km}$ west-east and $1000 \mathrm{~km}$ north-south, extending into the Borno Basin, NE Nigeria [2] [3]. It covers an average of $29 \%$ of the Chad basin total area $\left(691,473 \mathrm{~km}^{2}\right.$ of Niger's $1,267,000 \mathrm{~km}^{2}$ land area), making it the second largest basin in the Chad Basin after Chad [4]. The Eastern Basin has two distinct tectono-stratigraphy regions: 1) the Djado Basin and 2) the Eastern Niger Rift Basin (ENRB): an extensional asymmetric rift system consisting

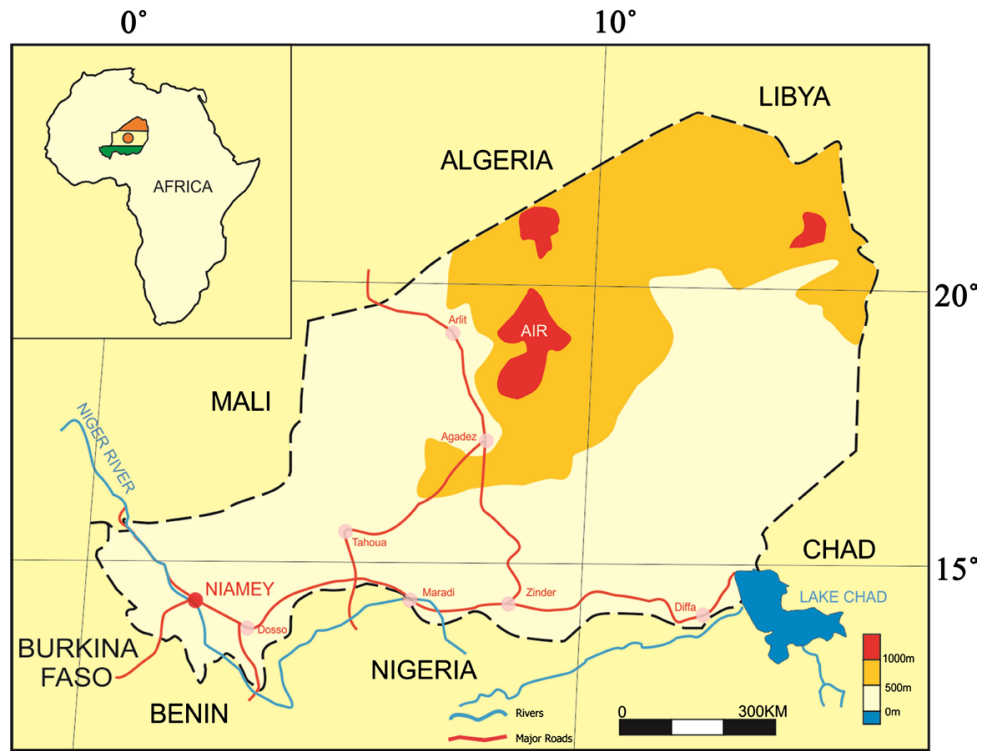

Figure 1. Location map of the Republic of Niger (modified after Zanguina et al., 1998). 
of Mesozoic-Cenozoic superimposed sedimentary successions overlying a PreCambrian crystalline basement and a Cambrian-Jurassic epimetamorphic basement (Figure 2).

The ENRB is part of the Chad Basin or West and Central Africa Rift system (WCARS) - a north central Africa intracratonic basin [5] of approximately 2,381,635 square kilometers [4] extending into Niger, Chad, Central Africa Republic, Cameroon, Nigeria, and Algeria [5] [6] [7]. Unlike the Western Basin, the ENRB is oil prolific and has six licensed blocks under operation out of the 35 available blocks [8]. Savannah Petroleum PLC (British) operates R1/R2 and R3/R4 blocks, China National Petroleum Corporation (CNPC) operates Agadem, Bilma and Ténéré blocks while Sonatrach operates Kafra (Figure 3).

Generally, little publication is available on the petroleum basin of Niger despite its four decades long exploration history. Two decades after the review of petroleum potential of Niger by [1] [9], lots of new understandings have emerged via efforts of oil industries using state-of-art techniques in exploration for oil and gas in the country. This paper presents a review and update of the basin and petroleum potential of the ENRB based on published works, previous reviews and information from the Niger Petroleum Ministry.

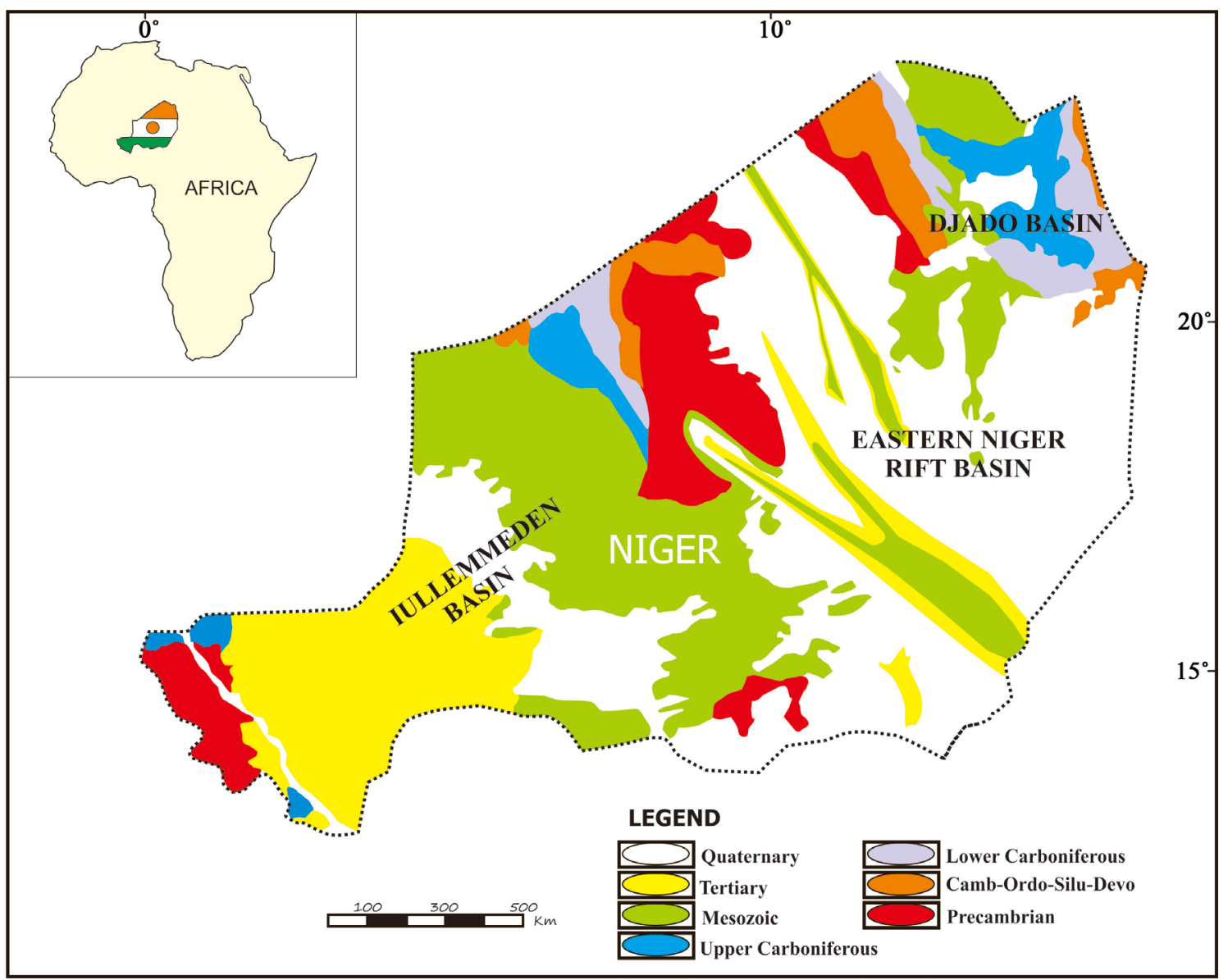

Figure 2. Geological map of Niger showing the location of the different sedimentary basins (modified from Harouna and Philp, 2012). 
$\dot{0}^{\circ}$

$10^{\circ}$

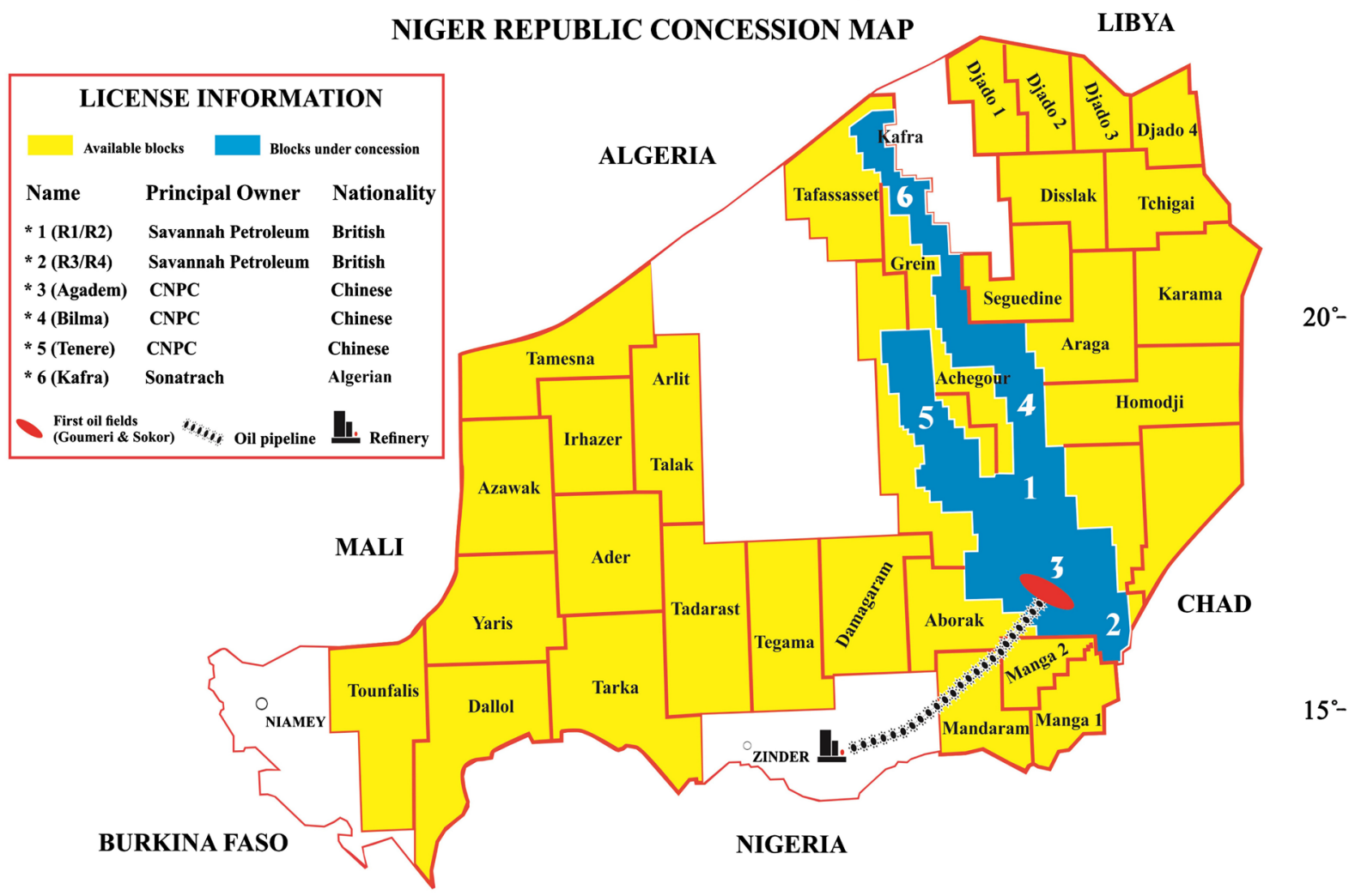

BENIN

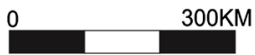

Figure 3. Map showing Niger current Oil and Gas blocs and licenses information (modified from Savannah Petroleum PLC, 2014).

\section{Exploration and Development History}

As early as the late 1950s, exploration was launched in West Basin (Tamesna-Talak and East Djado areas), however, in the Eastern Niger Rift Basin (ENRB) it was not until 1970 when Global Energy got a permit to explore Kafra Basin, NE of the ENRB; Esso began exploring Agadem Basin in the south in 1970, detecting oil shows in Madama and Yogou formations. Elf Petroleum got into Agadem Basin project in 1980, which led to more drilling, acquisition of the first modern 2D seismic surveys and the discovery of oil shows in Sokor Formation.

Between 1980 and 1998, Elf and Texaco co-explored the Agadem Basin by acquiring a joint permit in 1985, which was later renewed in 1990. In the same year, $50 \%$ of their acreage was relinquished and only 5 wells were drilled between 1990 and 1994. Another 25\% of the acreage was also relinquished in 1996 and Texaco acquired a new set of 2D seismic surveys. Between 1997 and 1998, three other bore holes were drilled and consequently, due to a low success rate, Elf withdrew in 1998 leaving Texaco as the sole operator until 2001.

In 2002, PETRONAS allied with Texaco in the Agadem Basin project, which continued until 2006, when both companies abandoned the Agadem Basin, 
deeming it uneconomical. The Agadem, approximately $30,000 \mathrm{~km}^{2}$ in area, with an estimated reserve of 328 million barrels of oil and nearly 10 billion $\mathrm{m}^{3}$ of gas, once again became the property of the state.

In 2007, the Agadem block was re-allocated to China National Petroleum Corporation (CNPC) through a public tender with a signed agreement between the CNPC and the Niger government (2008) to construct a 20,000 barrels/day capacity refinery in Niger on a share capital arrangement of $60 \%$ China and $40 \%$ Niger.

Between 2008 and 2012, CNPC acquired first ever 3D seismic lines (13,000 $\mathrm{km}^{2}$ ) over the Agadem Basin and more than $18,000 \mathrm{~km}^{2} 2 \mathrm{D}$ seismic lines. A total of 127 exploration wells were drilled with 97 being discovery wells.

In 2011, the first oil was produced from Sokor and Goumeri fields. The refinery was launched in the Zinder region, with well completions, construction of surface facilities and a $462.5 \mathrm{~km}$-long pipeline from the oil fields to the refinery realized.

The exploration success of CNPC in the Agadem block raised the estimated reserve to 3.5 billion barrels of oil from the 328 million barrels earlier recorded (over 1 billion barrels of recoverable oil at $30 \%$ recovery rate estimated) and about 17 billion $\mathrm{m}^{3}$ of gas from 10 billion (13 billion $\mathrm{m}^{3}$ recoverable). Eleven wells in Sokor yield a daily crude production of about 12,000 stb/d and ten wells in Goumeri yield a daily crude production of about $8000 \mathrm{stb} / \mathrm{d}$. In 2013, 20\% of CNPC Agadem license was sold to China Petroleum Corporation (CPC) Taiwan and the same year, portions of the Agadem acreage (R1/R2) were mandatorily relinquished.

Between 2014 and 2018, Savannah Petroleum Plc. was awarded the CNPC relinquished R1/R1 acreage. Another area, R3/R4 was also acquired in 2015 putting the total acreage at $13,655 \mathrm{~km}^{2}$. Savannah Petroleum has acquired a $36,948 \mathrm{~km}$ Full Tensor Gravity (FTG) survey (2015) and $806 \mathrm{~km}^{2}$ 3D seismic survey of a portion of R3 following its phase development plan. Three wells drilled (Bushiya-1, Amidigh-1 and Kunama-1) so far in the R3 acreage indicated light oil shows [10]. Recently, a fourth well (Eridal-1) also in the R3 acreage has proven successful. The R1/R2 acreage, which covers $30.5 \%$ of the CNPC Agadem area contains an estimated net reserve of 812 MMBBL.

\section{Tectonic and Structural Evolution of ENRB}

Tectonic rift system evolution of North Africa is divided into 5 phases: Phase-1: Pan-African crustal consolidation (594 - $434 \mathrm{Ma}$ ); Phase-2: Paleozoic-Jurassic platform development (550 - $130 \mathrm{Ma}$ ); Phase-3: Early Cretaceous-early rift (130 $98 \mathrm{Ma}$ ) to Late Cretaceous (98 - $75 \mathrm{Ma}$ ); Phase-4: Maastrichtian-Paleogene rift and emergence (75 - $30 \mathrm{Ma}$ ); and Phase-5: Neogene-Recent mainly emergence (30 - $0 \mathrm{Ma}$ ) [6] [11] [12] [13] [14] [15]. According to [7] [9] [16], the Phase-3 Early Cretaceous marked the breakup of Gondwana and the start of mechanical separation between South America and Africa, leading to the creation of the Western and Central Africa Rift System (WCARS) with its subunits; the West Africa Rift Subsystem (WAS) in Algeria, Niger, Nigeria and Chad, and Central 
Africa Rift Subsystem (CAS) in Chad, Cameroon and Central Africa Republic. Seven rift basins were formed in the WAS, (Grein, Kafra, Tenere, Tefidet, Termit, Bongor, and N'Dgel Edgi) and three rift basins in the CAS (Doba, Doseo and Salamat) [9].

The Phase-3 extensional tectonic led to the formation of the Eastern Niger Rift Basin (ENRB), evidence of an Early-Cretaceous sedimentation in the ENRB exists as intracontinental deposit [1] [17], consisting of gray lacustrine mudstone found only in western part of the Termit Basin [18].

The late tectonic event of phase- 5 incited a separation in the ENRB, creating north and south sections through the reactivation of the Agadez line: a lineament cutting through the center of the Niger Basin [9] [19] (Figure 4). The northern

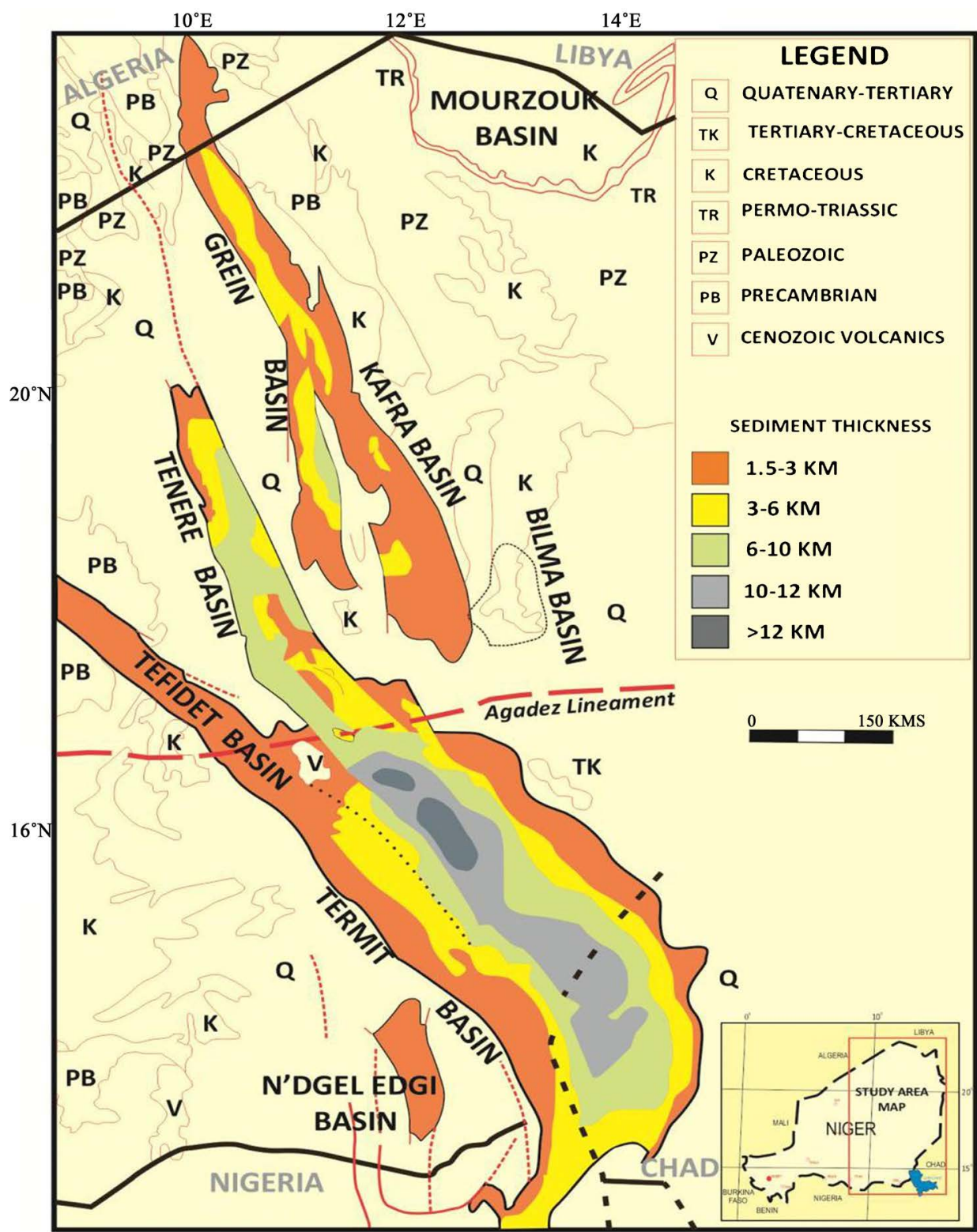

Figure 4. Simplified isopach of the Eastern Niger Rift Basin with surrounding generalized surface geology, red dash line; Agadez lineament (modified after Genik, 1992). 
sections are predominantly asymmetric half-grabens, while the southern section is predominantly full-grabens [1] [9] (Figure 5). The northern sections have experienced tectonic reversal and uplift [9] [20] while the south remained relatively stable with well-preserved thick sediment deposits as seen in the Termit Basin with no significant scale of tectonic reversal since the rifting process in the Early Cretaceous Epoch and hence has been well preserved [9].

In the Late Cretaceous, the ENRB switched from a tectonically controlled subsidence to a thermally controlled subsidence, coincidental with global sea level rise which led to marine sediments transgression from the Tethys Sea and the South Atlantic on its rifted blocks. In the Termit Basin, over $5 \mathrm{~km}$ thick sediments were deposited into a $150 \mathrm{~km}$ wide depression, while in the Tenere Basin, 4 to $6 \mathrm{~km}$ of marine, continental and lacustrine deposits formed during the thermal subsidence phase [9] [21].

In the Paleogene, thick Cenozoic continental sands, and shaly-sand sediments were deposited [18] unconformably on the Cretaceous deposits [22]. The Paleogene sequences north of the ENRB experienced tectonic reversal and uplift probably due to volcanism (the Gosso Lorom volcanic) along the Agadez lineament and the northwestern part of the Termit Basin [9].

Most of the WCARS Basins share similar tectono-stratigraphic history with little disparity among individual basins, which resulted from the controlling tectonic regime [23]. Late Eocene and younger sediments, rest unconformably on the older series as a result of intra-Eocene erosional and/or depositional hiatus [22]. Uplift in the WCARS was limited to the Santonian and intra-Eocene phases of intraplate compression [24].

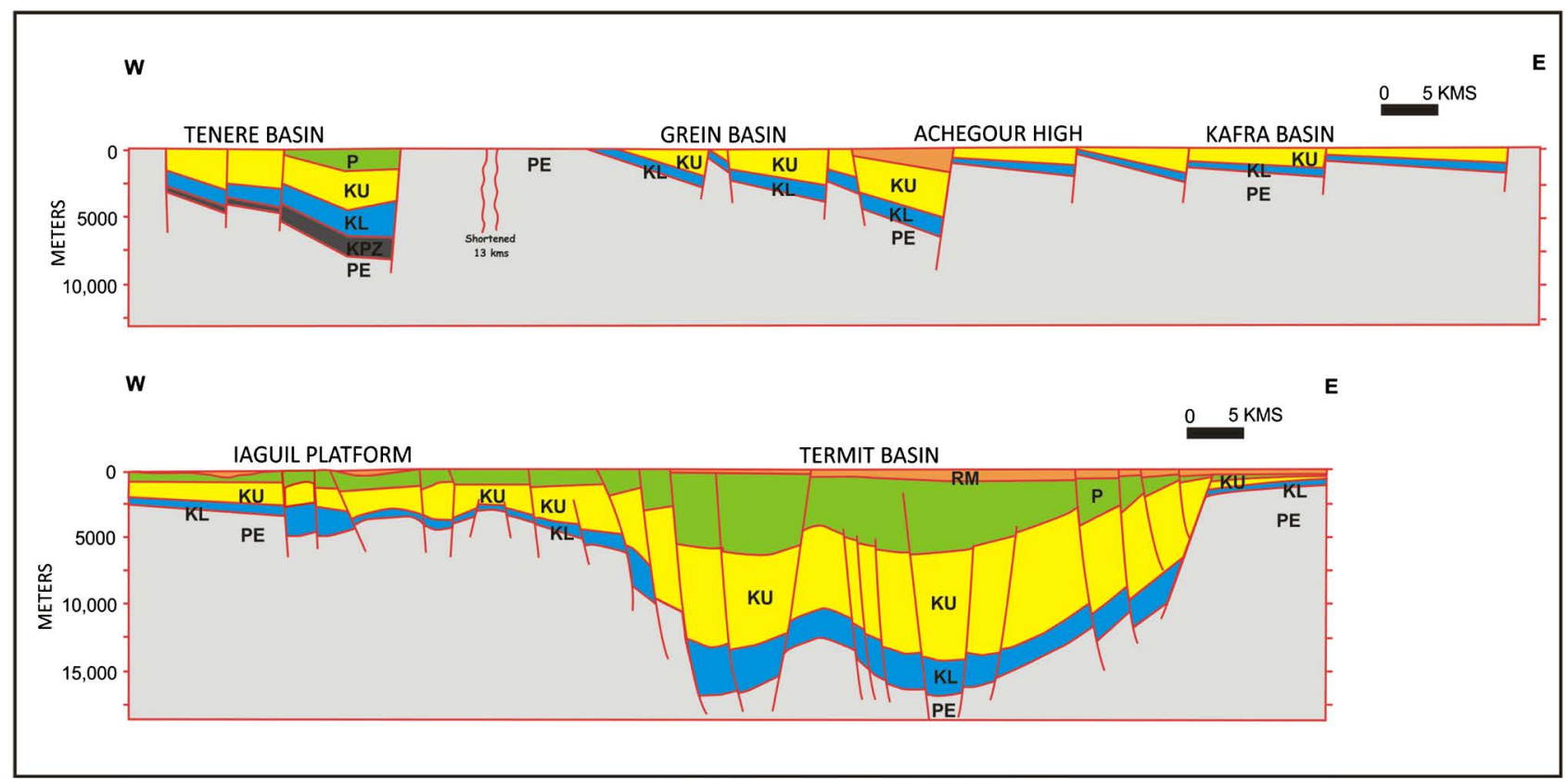

Figure 5. Seismically derived basin profiles of north (top) and south (bottom) of the ENRB. (Top) Tenere, Grein, Kafra basins are well defined asymmetric half-grabens. (Bottom) Termit basin showing Late Cretaceous Phase-3 and Palaeogene Phase-4 normal faulting (After Genik, 1992). 
Over four decades of research in the ENRB have revealed that it is a polyphase [25] [26] superimposed sedimentary basin [27] with both Cretaceous and Tertiary rifting phases [28] [29] [30]. An understanding of the syn-rift and post-rift break-up tectonism is essential for the study of sedimentary basin formation and major geodynamic events at conjugate margins [31] [32] [33] [34]. The Eastern Niger Rift Basin (ENRB), a western part of WAS, comparable in size to the North Sea Basin [20] has six of the rift grabens presented by [9] for WAS basins except for Bongor, which lies in Chad region. Another mappable rift graben in the ENRB is Bilma Basin [1] [2].

Rifting activities in the Early Cretaceous and the Paleogene produced fracture zones dominated mainly by large tilted, normally faulted blocks of different strikes and dips, [9] [17]. Some complex fault zones, like the Dinga fault bench, Araga graben and Fana transfer zone (FTZ) are found in the Termit Basin, south of the ENRB [17].

Based on activation timing, strike and tectonic control, the fault systems in ENRB comprise two sets;

1) The Early Cretaceous basement involved faults that trend NW-SE [21]. They have relatively large throws and flanked the boundaries of the basins. Many of these faults got reactivated during the Paleogene rifting cycle thus cut through the sedimentary strata below the Neogene-Quaternary sequences [17] (Figure 6). First order faults above the Agadez lineament, north of the ENRB trend NW-SE (Figure 7).

2) The Paleogene rifting cycle generated new sets of NNW-SSE-trending faults [35]. The Paleogene faults exist both along the boundaries of the basin and within the basin. Most of these Paleogene generated faults cut through the Upper Cretaceous to the Late Paleogene sedimentary strata [17] (Figure 6).

The faults orientation reflected a change in stress regime within the extending rift basin (Figure 7) probably triggered by contrast in the spreading rate of the Central and South Atlantic Ocean floor [24] [36]. Many faults in the FTZ, Trake Slope and Yogou Slope south of the Agadez lineament rotated in the NNW-SSE direction. This Paleogene tectonic faults re-orientation is represented physically by the folds and basin inversion within the FTZ strata in the ENRB and the Borno basin south of the ENRB [24] [37].

\section{Stratigraphy}

The stratigraphic record of the Eastern Niger Rift Basin (ENRB) is best preserved in the Termit depression at its southern part (Figure 8). The Termit depression is among the biggest in the West and Central Africa rift system (WCARS). It has the ENRB deepest depocenter with no records of basin uplift. It has relatively the most favorable petroleum system conditions. It has an estimated largest sediment thickness of around 12,000 $\mathrm{m}$ [5] [9].

These sediments include 300 - 2500 m of Lower Cretaceous terrigenous clastic, 800 - $4200 \mathrm{~m}$ of Upper Cretaceous shallow-marine shale, sandstones, siltstones 

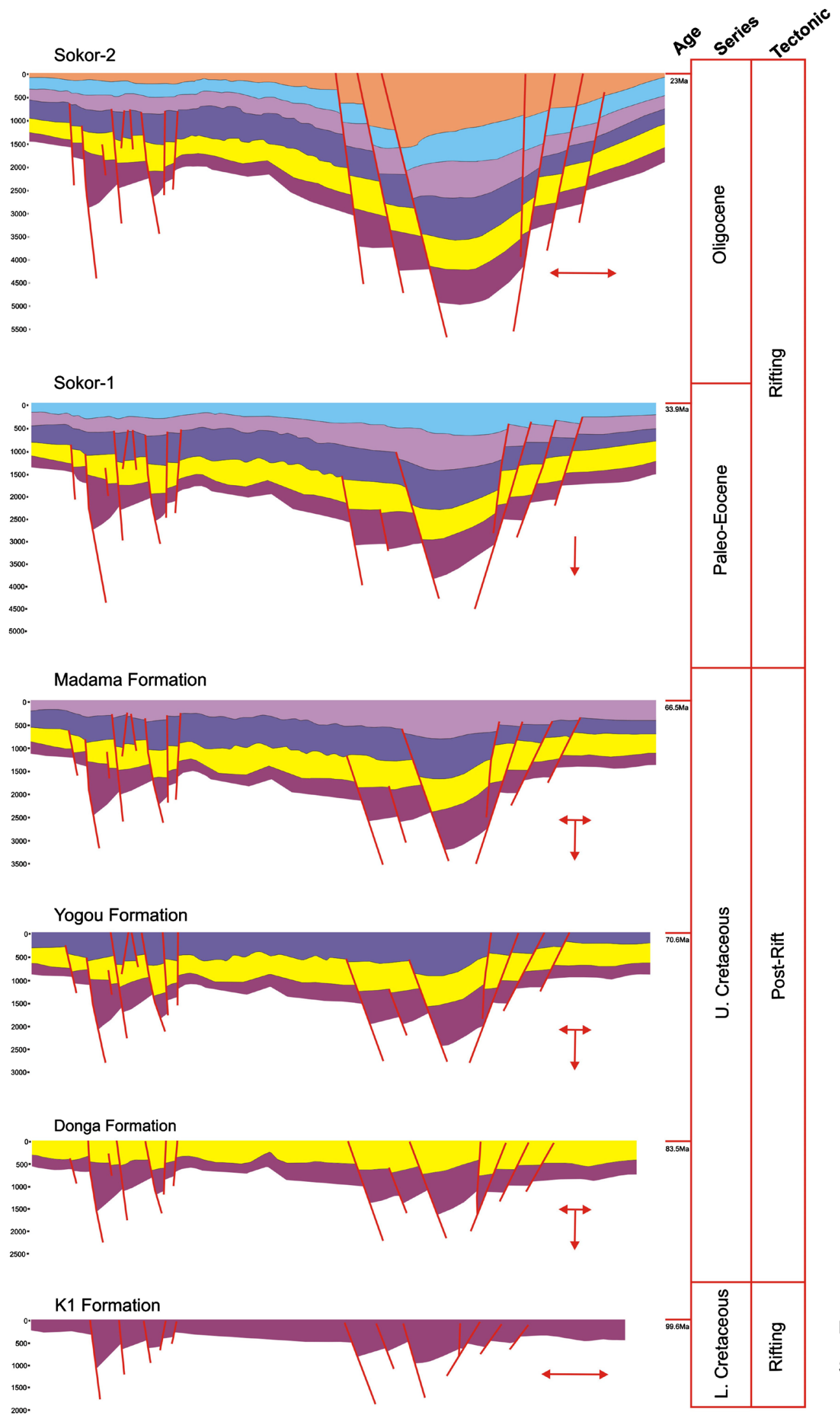

Extension $\longleftrightarrow$
Subsidence $\quad \downarrow$

Figure 6. Polyphase rift evolution of the Termit Basin in the Northern part of Niger Basin. 


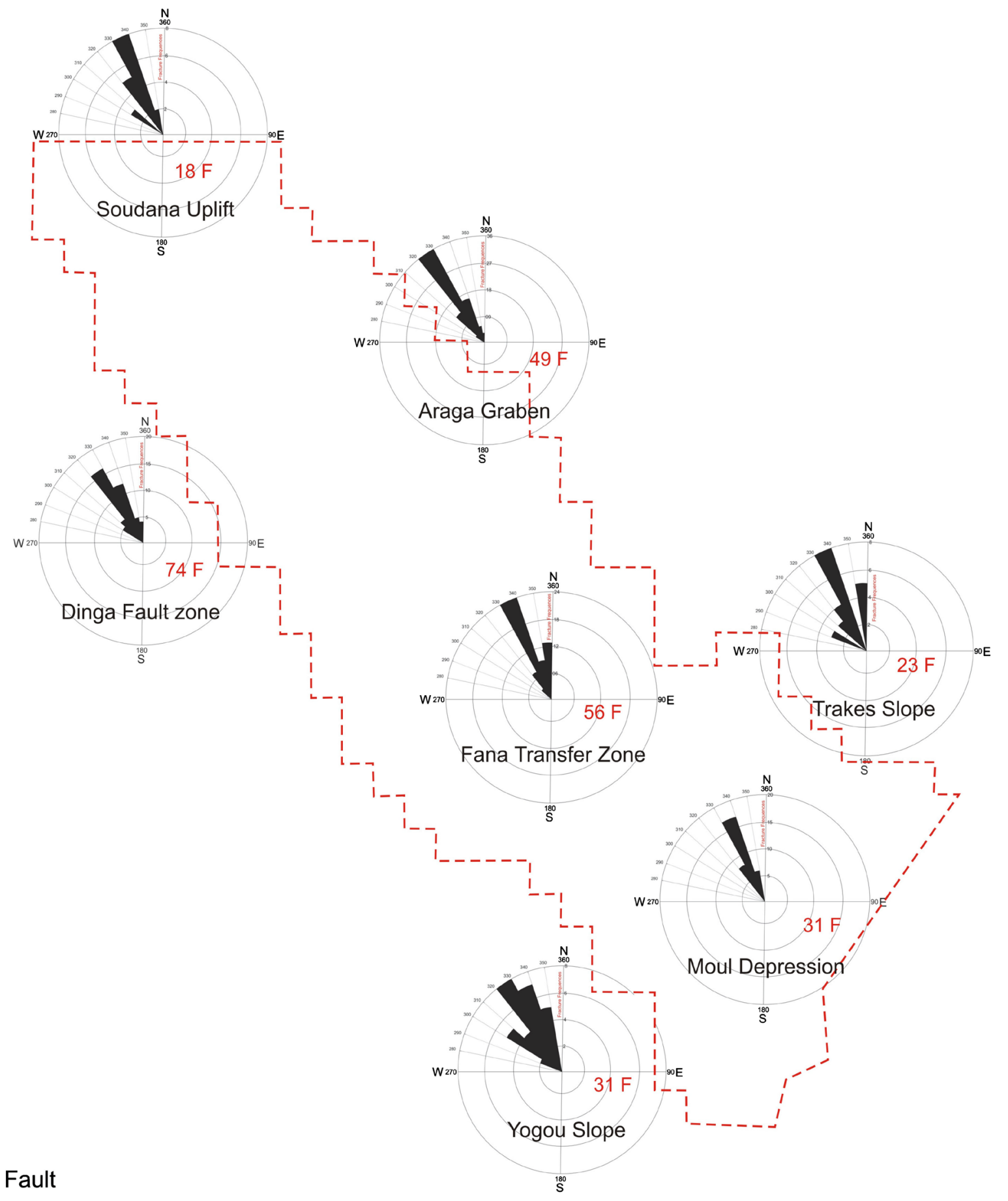

Total faults analyzed: 282

Rose diagram of stress regimes across Termit Basin

Figure 7. Rose diagrams across the different structural belts in Termit basin reflecting a change in stress regime within the extending rift basin. The dominant orientations are NNW-SSE-trending. 


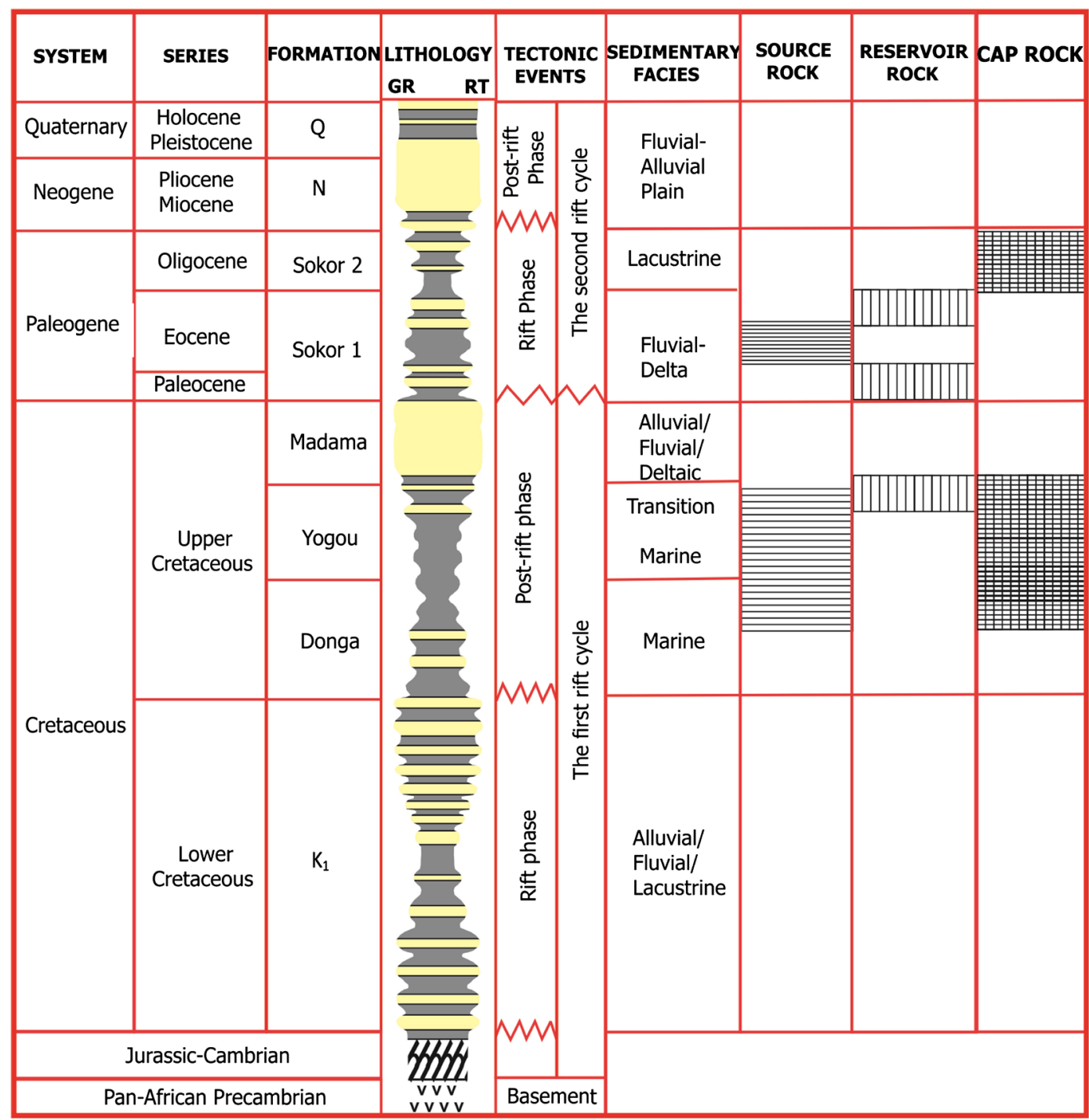

Sandstone

Shale/Mudstone

Basement

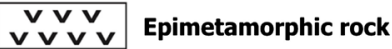

M Unconformity

Figure 8. Tectonostratigraphy and Petroleum System of ENRB (Modified after Xiao et al., 2019).

interbedded with minor carbonates and up to 350-2500 m Cenozoic continental sands, and shale sediments [18]. The Neogene and Quaternary sequences mainly consist of fluvial deposits eroded mostly in the northern section of the ENRB (Figure 9).

\section{Petroleum System of Eastern Niger Rift Basin (ENRB)}

\subsection{Source Rock}

The ENRB is known to have two oil families, the Upper Cretaceous lacustrine and marine source rocks, and the Paleogene source rocks [1] [7] [17] and [35]. Organic geochemical studies have documented three source rocks [17] [18] namely, the Paleogene Sokor-1 Member, the Upper Cretaceous Yogou Formation, and the 


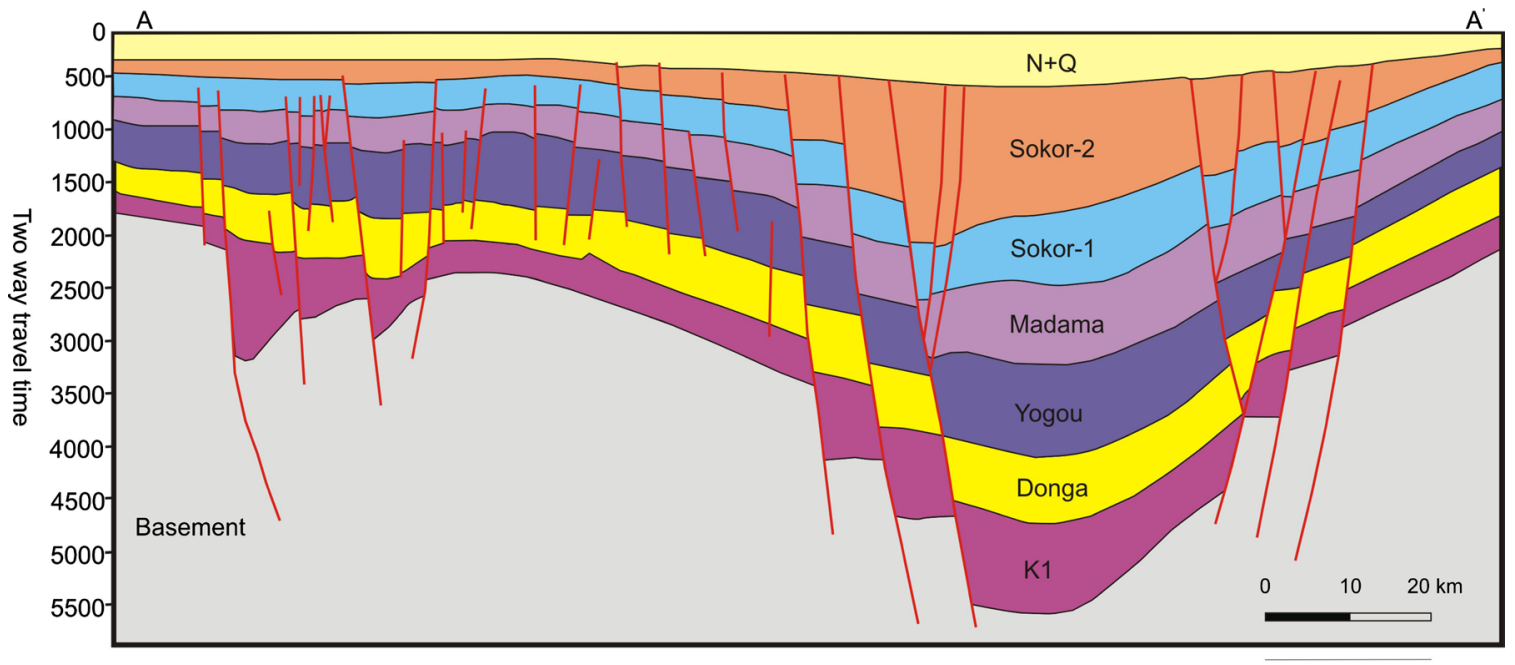

$16.6 \mathrm{Km}$

Figure 9. Seismic stratigraphy and faults settings of Southern Niger Basin (Modified after Liu et al., 2012).

Donga Formation, ranging from lacustrine to transitional and marine source [35] [38].

The Sokor-1 Member consists of fluvial deltaic alternating sandstone, mudstone and shale referred to as "Alternances de Sokor" [2] [20] with an estimated thickness of 300 meters [17]. Based on its petroleum importance, the "Alternances de Sokor" is divided into 5 pay zones: E1, E2, E3, E4 and E5. Geochemical analyses of Hydrogen Index (HI) and Oxygen Index (OI) placed the Sokor-1 Member as type II2 [17] and type II-III organic matter [35]. HI versus kerogen carbon isotope, placed the Sokor-1 Member in mainly terrestrial rich organic matter [18]. The Sokor-1 Members have TOC range of 0.37 - 15.48 and Rock-Eval S2 range of $0.16-92.70 \mathrm{mg} / \mathrm{g}$. They are good to excellent, mature source rock [2] [17], however, they are spatially limited [17].

The Upper Cretaceous Yogou Formation consist of wide-spread mudstone and shale rocks measuring $300-1000 \mathrm{~m}$ thick, which are stratigraphically divided into three third-order sequences namely; YSQ3, YSQ2 and YSQ1 from top to bottom [38] [39] and considered the most productive source rock in the ENRB [17] [38]. The TOC values of the YSQ2 and the YSQ1 marine source rocks ranges from $0.76 \%$ to $1.69 \%$ with mature to high mature thermal evaluation stage (Ro: $0.63 \%-1.29 \%$ ), while the TOC value of the YSQ3 transitional source rocks is relatively higher $(1.11 \%-6.63 \%)$; however, of relatively low maturation levels (Ro: $0.59 \%-0.91 \%$ ). Based on $\mathrm{H} / \mathrm{C}$ versus $\mathrm{O} / \mathrm{C}$ plot result by [35] and [38], the source rock is dominated by Type II2-III kerogen. The burial and maturity evolution suggest that the rocks are in the middle maturity stage [18] [35]. [18] classified the source rock of the Yogou Formation as high mature to wet gas stage in subsidence center and ranges from mid-mature to late mature in proximal of basin.

The Upper Cretaceous Donga Formation, equally wide-spread, consists of two lithological units; the lower-interval (mudstone) and the middle to upper-interval 
(siltstone) [18] both with total thickness average of 200 - $500 \mathrm{~m}$ [17]. The Donga source rocks TOC range between 0.41 - 2.50 [17] [18], Rock-Eval S2 range between 0.20 - $6.50 \mathrm{mg} / \mathrm{g}$ and HI averages $118 \mathrm{mg} \mathrm{HC/g}$ TOC [18]. The Donga source rock contains mainly type II2-III organic matter [17]. It has a relatively poor to fair source rocks despite its wide distribution and thus considered as secondary source rock [17].

The Lower Cretaceous Formation is a restricted formation of gray lacustrine mudstone found only in the western part of the Termit Basin and the Tenere Basin (Figure 6 and Figure 9). It has TOC range of $0.45 \%$ to $1.54 \%$ and is predominantly type III kerogen. These source rocks are very poor to poor quality with no significant contribution to oil discoveries in the Termit Basin [18]. The Upper Cretaceous Donga Formation and the Yogou Formation are the primary sources of hydrocarbons in the ENRB [18] [20] [38] while the Yogou Formation is the most productive [38]. Organic matter geochemical studies of the Donga Formation and the Yogou Formation [38] [39] subdivided the source elements into:

1) The Yogou (YSQ2 and YSQ1) Formations and Donga (DSQ2 and DSQ1) Formations belong to sub-oxic to anoxic marine environment and are richer in marine aquatic organisms such as algae and bacteria [39].

2) The Yogou (YSQ3) Formation belongs to sub-oxic to oxic environment and sub-oxic to transitional environment [38] and richer in higher plant and lower aquatic organisms in fresh-brackish water column [39].

\subsection{Reservoir Rocks}

The Upper Cretaceous Donga, Yogou, and Madama Formations and the Paleocene-Eocene Sokor-1 Members all have potential reservoir layers. However, the Upper Cretaceous Yogou and Eocene sandstones are the main reservoir intervals in respect to petroleum system [17]. Many of the Termit Basin high-yield oil fields discoveries like Dinga, Dibeilla and Fana are found within the Eocene Sokor-1 Member [17].

The Eocene Sokor-1 Member comprises of delta and lacustrine sandstones interbedded with mudstone/shale. The thicknesses of the Sokor five pay zones range from less than $1-50 \mathrm{~m}$, with about $98 \%$ less than $40 \mathrm{~m}$ [20]. The good sandstone beds have average porosity of $20 \%-28 \%$, and permeability from 250 md to 1 darcy [18].

The Madama Formation has massive sandstones with thin layer of muddy sandstones and coal seam [18], top reservoir quality with $25 \%-35 \%$ porosity [1] and good reservoir property in its upper 100 - $200 \mathrm{~m}$ thick sandstone as revealed by well data [20]. Its lower sequence of alternating sandstone and shale has some oil shows [20].

The Yogou (YSQ3) transition Formation, and the Yogou (YSQ1 and YSQ2) marine sandstones formations are important reservoirs for the Upper Cretaceous petroleum system [35]. The thickness of these reservoir beds varies from less than $1 \mathrm{~m}$ to $25 \mathrm{~m}$. The Upper Cretaceous Yogou Formation has a self-contained pe- 
troleum system [1] [17] undermined by its restricted vertical and lateral extents [7], lack of regional caps and numerous faulting events [35]. In Koulele area of the Termit Basin, south of the ENRB, reservoir porosity varies from $15 \%$ to $25 \%$, and the permeability varies from 5 to $200 \mathrm{mD}$ [35].

\subsection{Seal and Trap}

The ENRB is a superimposed sedimentary basin with one regional seal and multiple local seals found within the Paleogene and the Upper Cretaceous petroleum assemblages. Oligocene Sokor-2 Member (lacustrine mudstone) functions as a regional seal rock for the Sokor-1 reservoirs and for the Upper Cretaceous reservoir. According to [18], the average thickness of the regional seal over the deepest depression in the Termit Basin is about $100 \mathrm{~m}$ in the proximal and about $500 \mathrm{~m}$ in the basin central. The seal thins and fades out north of the Termit Basin, leaving the Tenere Basin with no regional seal due to uplift and erosion in the region [1] [21]. Mudstone and shale intercalation within the stacked Eocene Sokor-1 Member and the Upper Cretaceous Yogou Formation are also very effective as top and lateral seals. They serve as a local seal for separate reservoirs formed within the two assemblages [18].

\section{Geochemical Analyses of ENRB Oils}

\subsection{Oil-Oil Correlation (Termit Basin)}

Works of [2] and [18] carried out on oil samples from the Termit Basin using biomarker distributions and bulk stable carbon isotopic compositions identified two distinct types of oil in the Termit basin namely, Type 1 (Marine source rock origin) and Type 2 (Lacustrine source rock origin) (Table 1). Organic geochemistry and biomarkers studies on the Termit Basin oils show that all the oils were generated by source rocks within the main phase of the oil generation staged, equivalent vitrinite reflectance of $0.58 \%-0.87 \%$.

[38] conducted a geochemical study on oil samples and source rocks of the Upper Cretaceous Yogou Formation subunits (YSQ1, YSQ2 and YSQ3) from the Termit Basin, and reported that the tested oils have a close correlation to the YSQ2 and YSQ1 marine source rocks and are mainly derived from them, while a minor contribution is from the YSQ3 continental-transitional source. This result

Table 1. Evaluation of the main source rocks in the Termit Basin (modified after Zhou et al., 2017 and Xiao et al., 2019).

\begin{tabular}{|c|c|c|c|c|c|c|c|}
\hline \multirow{2}{*}{$\begin{array}{c}\text { Source Rock } \\
\text { Sokor-1 }\end{array}$} & \multirow{2}{*}{$\begin{array}{l}\text { Mudstone } \\
\text { (m) } \\
300\end{array}$} & \multicolumn{2}{|c|}{$\begin{array}{c}\text { TOC wt } \% \\
\text { Range-Mean }\end{array}$} & \multicolumn{2}{|c|}{$\begin{array}{c}\mathrm{S}_{1}-\mathrm{S}_{2}(\mathrm{mg} / \mathrm{g}) \text { Effective } \\
\text { Range-Mean }\end{array}$} & \multirow{2}{*}{$\begin{array}{c}\begin{array}{c}\text { Source Rock Area } \\
\text { per } \mathrm{Km}^{2}\end{array} \\
2700\end{array}$} & \multirow{2}{*}{$\begin{array}{c}\text { Evaluation } \\
\begin{array}{l}\text { Good-excellent, mature source rock, } \\
\text { limited distribution, major source rock }\end{array}\end{array}$} \\
\hline & & $0.37-15.48$ & 2.2 & $0.16-92.70$ & 12.40 & & \\
\hline Yogou & $400-1000$ & $0.50-16.10$ & 2.3 & $0.23-48.54$ & 4.37 & 18000 & $\begin{array}{l}\text { Good, mature source rock, basin-wide } \\
\text { distribution, major source rock }\end{array}$ \\
\hline Donga & $200-500$ & $0.41-2.50$ & 1.0 & $0.20-6.50$ & 1.37 & 2700 & $\begin{array}{l}\text { Moderate-poor source rock, wide } \\
\text { distribution, secondary source rock }\end{array}$ \\
\hline
\end{tabular}


agrees with the report of [35] that YSQ2 and YSQ1 marine shales controlled the source rocks in the Termit Basin Transfer zone.

The Sokor-1 Member is another package of important source rock and pay zone, generally buried shallower than the threshold hydrocarbon generation depth of $2400 \mathrm{~m}$, and therefore low in thermal maturity ( $\mathrm{R}$ of $0.3 \%-0.6 \%$ ). Oil reservoirs of the Sokor-1 located close to the depocenter in structural belt at the Dinga fault bench are matured and are highly consistent with the scope of effective source rock.

\subsection{Hydrocarbon Migration and Accumulation in the ENRB}

Two source-reservoir-seal assemblages are prominent in the ENRB. Samples of oils in the Termit Basin presented by [17] are from the Lower assemblage of Upper Cretaceous and Upper assemblage of Paleogene.

- The Upper assemblage of Paleogene which gets charged from the Upper Cretaceous Yogou Formation through fractures emplaced during the two rifting episodes. The multiphase tectonic events [7] have made the Paleogene upper assemblage more dominant in all structural belts across the basin [17] [40].

- The Lower assemblages are self-sourced type of source-reservoir-seal assemblage with relatively less migration distance. Oil generated within the Cretaceous source rocks is trapped within the same Cretaceous trap system except for where the trap is destroyed and oil re-migrates upward into the Paleogene upper assemblage.

The statics and dynamics of the Termit oil fields discussed by [41] using the relationship between the oil physical properties (Viscosity and Density) and migration distance within the Termit Basin documented that oils close to the source exhibited low density $\left(0.85-0.89 \mathrm{~g} / \mathrm{cm}^{3}\right)$ and low viscosity (15 - $\left.50 \mathrm{mPa} \cdot \mathrm{s}\right)$ while those far away from the source, exhibited a relative high density (0.90 $\left.0.93 \mathrm{~g} / \mathrm{cm}^{3}\right)$ and high viscosity (100 $\left.\mathrm{mPa} \cdot \mathrm{s}\right)$ as seen in the Dinga depression and the Araga-graben.

\subsection{Oil Migration Orientation and Charging Pathway in the ENRB}

Geochemical parameters of Ts/(Ts + Tm), 2, 4-/1, 4-dimethyldibenzothiophene ratios and homogenization temperatures of fluid inclusion (FI) [42] can be use to determine oil migration orientation, charge pathway and charging time. [40] and [41] applied the above methods on oils from the Termit Basin. Results of over 100 homogenisation temperature of oils from the Paleocene-Eocene Sokor-1 reservoir measured and plotted show a unimodel distribution pattern which is an indication of the entrapment temperature of FI for one oil charge event in the reservoir of the Termit basin [40]. [40], puts the charge time of oil in sandstone reservoir of Paleocene-Eocene Sokor-1 at $13 \mathrm{Ma}$ by converting the entrapment temperature of oil inclusion into geological age. Combining the homogenization temperatures $(\mathrm{Th}, \mathrm{oC})$ of fluid inclusions (FI) data with buri- 
al-thermal history, revealed that the Paleocene Sokor-1 pay zone and the Yogou Formation pay zone reservoir were charged once during 8 - $2 \mathrm{Ma}$ and 4 - $0 \mathrm{Ma}$, respectively [41]. Further from the oil geochemistry analyses, oil migrations in the ENRB Basin were determined and presented as follows: Oil migrates from SW to NE in the Araga-graben, from NE to SW in the Dinga Basin, from SE to NW along Fana Uplift, from North to South in the Moul Depression, from Dinga Depression to the NW part of the Termit Basin, and from Moul Depression to the SE of the Termit Basin.

\subsection{Impact of Fracture Style on Oil Migration in the ENRB}

Fault geometries across the ENRB impact many of the oil migration pathways and patterns expressed above. In the Termit Basin three prominent structural belts are known, each with a distinct fracture system, migration pattern, trap and accumulation model [17].

Depending on the strata the fault dissects, a single fault may play a role of trap or conduit [43] or both. The ENRB polycyclic sedimentations and fracture regimes [25], with its series of basins with their asymmetric faults, traps, fault deformation and juxtaposition. Migration pathways and patterns have been impacted by the fault dynamics and the source reservoir assemblages. For a large fault throw, lateral migration is disrupted, and vertical migration along the high-angle normal fault becomes predominant, while for a small fault throw, vertical migration is secondary to lateral migration [17]. Long distance migration exists for oils sourced from the Upper Cretaceous and trapped in the Paleogene assemblages, while short migration distance exists for oil generated and trapped within the Upper Cretaceous source-reservoir assemblages. Fault seal quantitative prediction is necessary for a profound understanding of fault roles in the ENRB basins. It will enhance the interpretation and prediction in oil migration models, and reduce the risk in petroleum system assessment.

\section{Conclusions}

Out of the five phases of tectonic event in the Africa rift systems, the phase- 3 and phase- 5 events are of greater importance to the evolution of Eastern Niger Rift Basin (ENRB). The phase-5 led to the formation of the ENRB, while the phase-3 led to the reactivation of the Agadez lineament and the re-orientation of the basin stress regime in the NNW-SSE direction. The Agadez lineament which separates the ENRB into north and south sections may have halted the spread of the neo-stress northward, thereby deepening the south section.

Two oil families (Type-1 and Type 2) have been documented for the two main pay zones; the Upper Cretaceous Yogou and the Eocene Sokor-1 respectively in the Termit.

Reports on hydrocarbon charging history in the Termit basin, indicated that oil charging event and migration history in the Termit basin as well as the rest of the ENRB is heterogeneous. 
This geologic heterogeneities and petroleum potential may not be unconnected with the pulse of volcanism and thermal under plating documented in some parts of the Chad Basins which may contribute to differential heating of the source beds.

Between the years 2008 to 2012, the estimated oil and gas reserves jumped from 328 million barrels of oil and 10 billion $\mathrm{m}^{3}$ of gas to 3.5 billion barrels of oil and about 17 billion $\mathrm{m}^{3}$ of gas due to improved techniques and data quality.

Observations support that different play units within the ENRB require different exploration approaches, therefore, it is strongly suggested that the concessioned and the unconcessioned blocks in the ENRB should be reassessed using fresh geological approaches and advanced technologies for new discoveries, and more accurate detection and estimation of the available hydrocarbon deposits.

\section{Acknowledgements}

The authors thank Dr Moussa Harouna and Dr Moussa Konate of Université Abdou Moumouni de Niamey for their comments and constructive suggestions that shaped the manuscript.

\section{Conflicts of Interest}

The authors declare no conflicts of interest regarding the publication of this paper.

\section{References}

[1] Zanguina, M., Bruneton, A. and Gonnard, R. (1998) An Introduction to the Petroleum Potential of Niger. Journal of Petroleum Geology, 21, 83-103. https://doi.org/10.1111/j.1747-5457.1998.tb00647.x

[2] Harouna, M. and Philip, R.P. (2012) Potential Petroleum Source Rocks in the Termit Basin, Niger. Journal of Petroleum Geology, 35, 165-185. https://doi.org/10.1111/j.1747-5457.2012.00524.x

[3] Okosun, E. (1995) Review of the Geology of Borno Basin. Journal Mining and Geology, 21, 113-122.

[4] Abdelkarim, A.M.A., Huneau, F., Hachim, M.S., Ketchemen Tandia, B., Fantong, W.Y., Rabe, S., Bobadji, I., Maduabuchi, C.M., Adegboyega, A.A. and Foto, E. (2017) Integrated and Sustainable Management of Shared Aquifer Systems and Basins of the Sahel Region Lake Chad Basin. RAF/7/011.

[5] Brownfield, M.E., Schenk, C.J., Charpentier, R.R., Klett, T.R., Cook, T.A., Pollastro, R.M. and Tennyson, M.E. (2010) Assessment of Undiscovered Oil and Gas Resources of the Chad Basin Province, North-Central Africa: U.S. Geological Survey Fact Sheet 2010-3096, 2 p.

[6] Fairhead, J.D. (1986) Geophysical Controls on Sedimentation within the African Rift Systems. In: Frostick, L.E., Renaut, R.W., et al., Eds., Sedimentation in the African Rifts, Geological Society, London, Special Publications 25, 19-27. https://doi.org/10.1144/GSL.SP.1986.025.01.03

[7] Genik, G.J. (1993) Petroleum Geology of Rift Basins in Niger, Chad, and Central African Republic. AAPG Bulletin, 77, 1405-1434.

https://doi.org/10.1306/BDFF8EAC-1718-11D7-8645000102C1865D 
[8] Africa Energy Intelligence, November 10, 2010. http://www.africaintelligence.com

[9] Genik, G.J. (1992) Regional Framework, Structural and Petroleum Aspects of Rift Basins in Niger, Chad and the Central African Republic (C.A.R.). Tectonophysics, 213, 169-185. https://doi.org/10.1016/B978-0-444-89912-5.50036-3

[10] Savannah Petroleum (2018) Kunama Oil Discovery and Exercise of Drilling Rig Option. 11 July 2018.

[11] Burke, K.C. (1976) The Chad Basin: An Active Intra-Continental Basin. Tectonophysics, 36, 197-206. https://doi.org/10.1016/B978-0-444-41549-3.50018-9

[12] Fairhead, J.D. (1988) Mesozoic Plate Tectonic Reconstructions of the Central South Atlantic Ocean: The Role of the West and Central African Rift System. Tectonophysics, 155, 181-191. https://doi.org/10.1016/0040-1951(88)90265-X

[13] Popoff, M. (1988) Du Gondwana a' l'Atlantique sud: Les connexions du fosse de la Benoue avec les bassins du nordest Brésilien jusqu'à, l'ouverture du Golfe du Guinée au Crétacé inferieur. Journal of African Earth Sciences, 7, 409-431. https://doi.org/10.1016/0899-5362(88)90086-3

[14] Benkhelil, J. (1988) Structure et evolution géodynamique du bassin intracontinental de la Bénoué, Nigeria. Bulletin des Centres de Recherches Exploration-Production Elf-Aquitaine, 12, 29-128.

[15] Fairhead, J.D. and Binks, R.M. (1991) Differential Opening of the Central and South Atlantic Oceans and the Opening of the Central African Rift System. Tectonophysics, 187, 191-203. https://doi.org/10.1016/0040-1951(91)90419-S

[16] Fairhead, J.D. and Green, C.M. (1989) Controls on Rifting in Africa and the Regional Tectonic Model for the Nigeria and East Niger Rift Basins. Journal of African Earth Sciences, 8, 231-249. https://doi.org/10.1016/S0899-5362(89)80027-2

[17] Zhou, L.H., Su, J.Q., Dong, X.W., Shi, B.Q., Sun, Z.H., Qian, M.L., Lou, D. and Liu, A.P. (2017) Controlling Factors of Hydrocarbon Accumulation in Termit Rift Superimposed Basin, Niger. Petroleum Exploration and Development, 44, 358-367. https://doi.org/10.1016/S1876-3804(17)30042-3

[18] Wan, L.K., Liu, J.G., Mao, F.J., Lv, M.S. and Liu, B. (2014) The Petroleum Geochemistry of the Termit Basin, Eastern Niger. Marine and Petroleum Geology, 51, 167-183. https://doi.org/10.1016/j.marpetgeo.2013.11.006

[19] Guiraud, R., Issawi, B. and Bellion, Y. (1985) The Guineo Nubian Lineaments, a Major Structural Zone of the African Plate. Comptes Rendus de PAcadémie des Sciences, 11, 17-20.

[20] Savannah Petroleum (2014) Savannah Petroleum Plc. Aim Admission Document. 25-95.

[21] Guiraud, M. and Maurin, J.C. (1992) Early Cretaceous Rifts of Western and Central Africa: An Overview. Tectonophysics, 213, 153-168. https://doi.org/10.1016/0040-1951(92)90256-6

[22] Guiraud, R., Binks, R.M., Fairhead, J.D. and Wilson, M. (1992) Chronology and Geodynamic Setting of Cretaceous-Cenozoic Rifting in West and Central Africa. Tectonophysics, 213, 227-234. https://doi.org/10.1016/B978-0-444-89912-5.50039-9

[23] Yassin, A.M., Hariri, M.M., Adbullatif, O.M. and Korvin, G. (2017) Evolution History of Trans-Tensional Pull-Apart, Oblique Rift Basin and Its Implication on Hydrocarbon Exploration: A Case Study from Sufyan Sub-Basin, Muglad Basin, Sudan. Marine and Petroleum Geology, 79, 282-299. https://doi.org/10.1016/j.marpetgeo.2016.10.016

[24] Guiraud, M. (1993) Late Jurassic Rifting-Early Cretaceous Rifting and Late Creta- 
ceous Transpressional Inversion in the Upper Benue Basin (NE Nigeria). Bulletin Centres Recherches Exploration-Production Elf-Aquitaine, 17, 371-383.

[25] Liu, B., Pan, X., Wan, L., Mao, F., Liu, J., Lu, M., Wang, Y., Chen, Z. and Jiang, H. (2012) Polyphase Rift Evolution of the Termit Basin, Eastern Niger: Constraints from Structural and Sedimentary Records. Geoscience, 26, 317-325.

[26] Harouna, M., Pigott, J.D. and Philp, R.P. (2017) Burial History and Thermal Maturity Evolution of the Termit Basin, Niger. Journal of Petroleum Geology, 40, 277-297. https://doi.org/10.1111/jpg.12676

[27] Tang, L., Huang, T., Jin, W., Lu, Z., He, C., Ning, F., Wang, P. and Chen, Q. (2009) Differential Deformation and Hydrocarbon Accumulation in the Superimposed Basins. Earth Sciences Frontiers, 16, 13-22. https://doi.org/10.1016/S1872-5791(08)60099-8

[28] Xue, L.Q., Wan, L.K. and Mao, F.J. (2012) Petroleum Migration and Accumulation in Termit Depression of East Niger Basin and Implications for Discovery of Well Dibeilla. Oversea Exploration, No. 4, 53-60. (In Chinese)

[29] Liu, B., Wan, L.K., Mao, F.J., Liu, J., Lü, M.S. and Wang, Y. (2015) Hydrocarbon Potential of Upper Cretaceous Marine Source Rocks in the Termit Basin, Niger. Journal of Petroleum Geology, 38, 157-175. https://doi.org/10.1111/jpg.12604

[30] Lü, M.S., Xue, L.Q. and Wan, L.K. (2015) Main Controlling Factors of Paleogene Hydrocarbon Accumulation of Termit Basin, West African Rift System. Earth Science Frontiers, 22, 207-216. (In Chinese)

[31] Allen, P.A. and Allen, J.R. (1990) Basin Analysis: Principles and Applications. Blackwell Scientific Publications, Oxford.

[32] Allen, P.A. and Allen, J.R. (2005) Basin Analysis: Principles and Applications. Blackwell Scientific Publications, Oxford, 549 p.

[33] Sinclair, I.K. and Withjack, M.O. (2008) Mid to Late Cretaceous Structural and Sedimentary Architecture at the Terra Nova Oilfield, Offshore Newfoundland-Implications for the Tectonic History of the North Atlantic. In: Brown, D.E., Ed., Central Atlantic Conjugate Margins, Dalhousie University, Halifax, 125-141.

[34] Silverstein, A., Silverstein, V. and Nunn, L.S. (2009) Plate Tectonics. Twenty First Century Books. 120 p.

[35] Wang, X., Wan, L., Jiang, Z., Liu, R., Wang, X.B., Tang, W., Gao, Y., Liu, S. and Xu, W. (2017) Controlling Factors and Accumulation Model of Hydrocarbon Reservoirs in the Upper Cretaceous Yogou Formation, Koulele Area, Termit Basin, Niger. Journal of Earth Science, 28, 1126-1134. https://doi.org/10.1007/s12583-016-0936-5

[36] Janssen, M.E., Stephenson, R.A. and Cloetingh, S. (1995) Temporal and Spatial Correlations between Changes in the Motions and the Evolution of Rifted Basins in Africa. GSA Bulletin, 107, 1317-1332. https://doi.org/10.1130/0016-7606(1995)107<1317:TASCBC>2.3.CO;2

[37] Avbovbo, A., Ayoola, E. and Osahon, G. (1986) Depositional and Structural Styles in Chad Basin of Northeastern Nigeria. AAPG Bulletin, 70, 1787-1798. https://doi.org/10.1306/94886D21-1704-11D7-8645000102C1865D

[38] Xiao, H., Wang, T.G., Li, M., Lai, H., Liu, J., Mao, F. and Tang, Y. (2019) Geochemical Characteristics of Cretaceous Yogou Formation Source Rocks and Oil-Source Correlation within a Sequence Stratigraphic Framework in the Termit Basin, Niger. Journal of Petroleum Science and Engineering, 172, 360. https://doi.org/10.1016/j.petrol.2018.09.082

[39] Lai, H., Li, M., Liu, J., Mao, F., Xiao, H., He, W. and Yang, L. (2018) Organic Geo- 
chemical Characteristics and Depositional Models of Upper Cretaceous Marine Source Rocks in the Termit Basin, Niger. Palaeogeography, Palaeoclimatology, Palaeoecology, 495, 292-308. https://doi.org/10.1016/j.palaeo.2018.01.024

[40] Liu, J., Zhang, Z., Li, Y., Tang, H., Xiao, H., Lai, H. and Yang, C. (2019) Oil Charge History of Paleogene-Eocene Reservoir in the Termit Basin (Niger). Australian Journal of Earth Sciences, 66, 597-606. https://doi.org/10.1080/08120099.2019.1568301

[41] Zhao, J. and Li, M. (2016) The Oil Migration Pathway and Hydrocarbon Charging History of Petroleum Systems in Termit Basin, Eastern Niger. AAPG Annual Convention and Exhibition, Calgary, 19-22 June 2016, AAPG Search and Discovery Article 80560.

[42] Bodnar, R.J. (2003) Introduction to Fluid Inclusions. In: Samson, I., Anderson, A. and Marsh, D., Eds., Fluid Inclusions: Analysis and Interpretation, Mineral. Assoc. Canada, Short Course 32, 1-8.

[43] Moretti, I. (1998) The Role of Faults in Hydrocarbon Migration. Petroleum Geoscience, 4, 81-94. https://doi.org/10.1144/petgeo.4.1.81 